\title{
DISCUSSÕES ACERCA DA CONSTITUCIONALIDADE DA PROVA PERICIAL OBTIDA POR MEIO DE BANCO DE DADOS DE PERFIL GENÉTICO
}

\section{DISCUSSIONS ABOUT THE CONSTITUTIONALITY OF THE EXPERT EVIDENCE OBTAINED THROUGH THE GENETIC PROFILE DATA BASE}

\author{
Jessé Lindoso Rodrigues ${ }^{1}$, Yasmim Pinto Leite ${ }^{2}$ \\ Thayara Castelo Branco ${ }^{3}$
}

\begin{abstract}
RESUMO: Objetiva-se com o presente trabalho fomentar a discussão acerca da prova pericial obtida através do banco de dados de perfil genético. Propõe-se analisar o método de identificação criminal introduzido pela Lei $\mathrm{n}^{\circ} 12.654 / 2012$ e as suas consequências no ordenamento jurídico pátrio à luz dos eventuais conflitos com o princípio do nemo tenetur se detegere. Para o desenvolvimento, buscou-se estabelecer, primeiramente, o suporte básico teórico para a devida compreensão do tema, para, em seguida, adentrar em questões mais profundas, sistemáticas, principiológicas, base para a discussão do caso concreto ora proposto, em que se discutirá a polêmica em torno da constitucionalidade (ou não) da prova pericial obtida por meio de banco de dados genéticos.
\end{abstract}

PALAVRAS-CHAVE: Processo Penal. Prova Pericial. Banco de Dados de Perfil Genético.

ABSTRACT: The goal of this work is to promote the discussion about the expert evidence obtained through the genetic profile database. It is proposed to be analyzed the method of criminal identification introduced by Law $\mathrm{n}^{\circ} 12654 / 2012$ and its consequences in the national legal order in the light of any conflicts with the principle of nemo tenetur se detegere. For development, it was sought to establish, first, the basic theoretical support for the proper understanding of the topic, and then to enter into deeper, systematic, and principleological issues, the basis for the discussion of the concrete case proposed here, in which one discusses the controversy around the constitutionality (or not) of the expert evidence obtained through the genetic database.

KEYWORDS: Criminal Proceeding. Expert Report. Genetic Profile Database.

\footnotetext{
${ }^{1}$ Acadêmico do Curso de Direito na Universidade Ceuma, integrante do NEVIC - Núcleo de Estudos em Violência e Cidadania. E-mail: jesselindosorodrigues@ hotmail.com

${ }^{2}$ Acadêmica do Curso de Direito na Universidade Ceuma, integrante do NEJUPEC - Núcleo de Estudos em Justiça, Poder e Ética na Contemporaneidade. E-mail: yasminleite@ hotmail.com

${ }^{3}$ Advogada. Membro da Comissão de Direitos Humanos da OAB/MA. Doutora e mestra em Ciências Criminais pela Pontifícia Universidade Católica do Rio Grande do Sul (PUCRS). Docente do curso de Direito da Universidade CEUMA. Integrante do Núcleo de Estudos e Pesquisas em Violência e Cidadania/NEVIC CEUMA. Coordenadora da Pós-Graduação em Ciências Criminais da Universidade CEUMA. Professora Substituta da Universidade Estadual do Maranhão/UEMA. E-mail: thaybranco@yahoo.com.br
} 


\section{INTRODUÇÃO}

A evolução da sociedade moderna, marcada por características muito peculiares como, por exemplo, o acelerado e constante avanço tecnológico, influenciou, de modo significativo, o nosso ordenamento jurídico. Com o Direito Penal (material e processual) não foi diferente, ao ponto em que este se viu obrigado a se adaptar a tais avanços tecnológicos e modernizar a sua máquina retrospectiva, visando melhorar a prestação jurisdicional na solução de conflitos e dar uma resposta ao clamor popular por políticas públicas mais eficientes e dirigidas ao combate à violência.

É nesse contexto de modernização da persecutio criminis, que a Lei $\mathrm{n}^{\circ}$ 12.654 é promulgada em 2012, alterando dispositivos das Leis $n^{\circ} 12.037 / 2009$ - que dispõe sobre a identificação criminal do civilmente identificado - e da Lei $\mathrm{n}^{\circ}$ 7.210/1984 (Lei de Execução Penal). No que tange à primeira, estabeleceu-se a coleta de material biológico do investigado, desde que houvesse autorização judicial para tal feito. No tocante à segunda, determinou-se que, nos casos de crimes dolosos com violência de natureza grave contra pessoa e crimes previstos como hediondos, os condenados fornecessem material biológico de forma automática.

Tal lei determinou ainda, que esses dados coletados seriam armazenados em um banco de dados de perfis genéticos gerenciado por unidade oficial de perícia criminal, regulado pelo Decreto $n^{\circ} 7.950 / 2013$ (que instituiu o Banco Nacional de Perfis Genéticos e a Rede Integrada de Bancos de Perfis Genéticos).

Em maio de 2016 o Supremo Tribunal Federal foi provocado a discutir sobre a constitucionalidade de algumas destas alterações, como por exemplo, a alteração que incluiu o art. 9-A a Lei $n^{\circ}$ 7.210/1984 (Lei de Execução Penal), prevendo a obrigatoriedade da extração do DNA e armazenamento em bancos de dados genéticos para fins de identificação do perfil genético do apenado. Trata-se do Recurso Extraordinário 973.837, que teve repercussão geral reconhecida, por unanimidade, pelo Plenário Virtual da Corte. Na origem, o recurso fora interposto contra acórdão do Tribunal de Justiça de Minas Gerais, em que a defesa de um condenado alega que esta medida viola o princípio constitucional da não autoincriminação (nemo tenetur se detegere).Com o reconhecimento da repercussão geral, cumpre dizer que a decisão a ser tomada pelo STF quanto ao mérito do recurso deverá ser aplicada aos casos análogos 
que, até o trâmite final do Recurso Extraordinário, ficarão sobrestados nas demais instâncias (aguardando o julgamento deste).

Feitas estas considerações iniciais, fixe-se aqui a problematização deste artigo, a saber: à luz do princípio constitucional do nemo tenetur se detegere, não seria inconstitucional a obrigatoriedade da coleta de DNA de condenados por crimes violentos ou hediondos com o objetivo de mantê-los armazenados em um banco de dados estatal com material genético?

À luz desta problemática, objetiva-se fomentar a discussão acerca da constitucionalidade ou não da coleta e armazenamento de DNA de condenados por crimes hediondos ou de natureza grave contra a pessoa em bancos de dados genéticos e, por conseguinte, a possibilidade de sua utilização na persecução penal.

\section{BREVES APONTAMENTOS SOBRE AS ALTERAÇÕES PROMOVIDAS PELA LEI No 12.654/2012}

A Lei $\mathrm{n}^{\circ}$ 12.654, promulgada em 2012, alterou alguns dispositivos das Leis $\mathrm{n}^{\mathrm{o}} 12.037 / 2009$ - que dispõe sobre a identificação criminal do civilmente identificado -, e também da Lei $n^{\circ} 7.210$ - Lei de Execução Penal. As alterações tiveram o objetivo precípuo de prever a coleta de perfil genético como forma de identificação criminal. Assim, dada a importância de tais alterações para a compreensão do tema abordado, passa-se a apontar alguns dispositivos da referida lei que foram objeto de modificação ou inovação.

De início, cumpre dizer que, no processo penal a prova pericial é fruto do exame procedido por pessoa que tenha conhecimento técnicos, científicos ou domínio específico em determinada área do conhecimento (TÁ VORA, 2013, p. 413). A Lei 12.654/2012, acrescentando o art. 5'-A à Lei 12.037/2009, fez questão de deixar bem claro de quem é a competência para armazenar tais informações. $\mathrm{O}$ dispositivo afirma que "os dados relacionados à coleta do perfil genético deverão ser armazenados em banco de dados de perfis genéticos, gerenciado por unidade oficial de perícia criminal”.

Jacques e Minervino (2007, p. 17-20) apontam que os maiores temores em relação ao uso inadequados das amostras genéticas constantes dos bancos de dados residem justamente na possibilidade manipular e divulgar informações sensíveis dos indivíduos como, por exemplo, a propensão a determinadas doenças, o que permitiria a 
empresas e seguradoras negar assistência e/ou emprego e promover a discriminação genética.

Uma das reflexões propostas refere-se justamente à possibilidade de manipulação inadequada do material genético constante dos bancos de dados genéticos de forma a validar, agora com base científica, a estigmatização e a discriminação.

Nesse contexto, a Lei $\mathrm{n}^{\mathrm{o}}$ 12.654/2012, acrescentando o art. 5\%-A à Lei $12.037 / 2009$, teve o cuidado de, em seu $\S 1^{\text {o }}$, dizer que "as informações genéticas contidas nos bancos de dados de perfis genéticos não poderão revelar traços somáticos ou comportamentais das pessoas, exceto determinação genética de gênero, consoante as normas constitucionais e internacionais sobre direitos humanos, genoma humano e dados genéticos". No parágrafo $2^{\circ}$, a lei previu consequências e responsabilização em todas as esferas possíveis para aqueles que desrespeitarem a tal preceito, afirmando que “os dados constantes dos bancos de dados de perfis genéticos terão caráter sigiloso, respondendo civil, penal e administrativamente aquele que permitir ou promover sua utilização para fins diversos dos previstos nesta Lei ou em decisão judicial”.

Importante também levantar informações necessárias acerca do perito. Perito é um auxiliar do juízo, dotado de conhecimentos técnicos ou científicos específicos sobre determinada área do conhecimento humano. Os peritos podem ser de duas espécies: peritos oficiais e peritos não oficiais. Neste ponto, a Lei $n^{\circ}$ 12.654/2012 trouxe importante previsão, acrescentando o art. $5^{\circ}$-A à Lei $n^{\circ} 12.037 / 2009$ que, em seu $\S 3^{\circ}$, prevê que "as informações obtidas a partir da coincidência de perfis genéticos deverão ser consignadas em laudo pericial firmado por perito oficial devidamente habilitado".

Acrescentou, também, o “Art. 7o-A, estabelecendo que esses materiais não ficariam preservados ad eternum, ao contrário, afirma que "a exclusão dos perfis genéticos dos bancos de dados ocorrerá no término do prazo estabelecido em lei para a prescrição do delito".

No que tange à fase investigatória, com a nova redação do artigo $7^{\circ}-\mathrm{B}$ da Lei $\mathrm{n}^{\circ} 12.037 / 2009$, fica disposto que o material genético coletado "será armazenado em banco de dados sigiloso" e estará disponível para acesso das polícias federal e civil, desde que atendido o requisito previsto no artigo $3^{\circ}$, parágrafo IV, combinado com o parágrafo único do artigo $5^{\circ}$ da mesma Lei. 
Portanto, ainda que já tenha sido feita a identificação civil do suspeito, pelos meios tradicionais, poderá ser autorizada a identificação genética desde que "essencial às investigações policiais, segundo despacho da autoridade judiciária competente".

Antes da referida lei, a coercitividade do Estado ao determinar que um indivíduo civilmente identificado sofresse também a identificação criminal, alcançava apenas a parte externa do seu corpo, quer fosse por suas impressões digitais, que fosse por fotografia. Agora, impõe-se uma "retirada coercitiva de parte do corpo, para adentrar no profundo de sua estrutura biológica [...]”.

Não obstante, à exigência de que a autoridade policial ou Ministério Público fundamente o pedido e comprove ser esse o único meio de prova possível para determinar a autoria do delito, uma intervenção corporal - ainda que consentida afronta diretamente o Princípio da Dignidade da Pessoa Humana e todas as garantias dele decorrentes. Nessa linha, alerta Lopes Jr. (2012, p. 6), que o juiz poderá, de ofício, determinar a coleta do material genético do acusado, afrontando assim, os preceitos estruturantes do sistema acusatório.

Outro instituto legal que sofreu modificação foi a Lei de Execução Penal, Lei $\mathrm{n}^{\mathrm{o}} 7.210 / 84$. Nesse caso, o condenado por crime hediondo ou por crime doloso cometido com violência grave contra a pessoa será, obrigatória e independente de autorização judicial, submetido à identificação criminal genética.

$\mathrm{Na}$ fase de execução da pena, a finalidade deste banco de dados é coletar e armazenar material genético para elucidar crimes futuros com autoria ignorada. Determina a lei que havendo inquérito instaurado, a autoridade policial, federal ou estadual, pedirá autorização ao juiz para acessar o banco de dados de perfis genéticos dos condenados. Apesar de a Lei 12.654/2012 declarar objetivos diversos, Queijo (2013, p.8) entende que a coleta de material genético tem por único a identificação de autoria de delito, em persecuções penais futuras, ou naquela que está em andamento. Para a autora a finalidade não é a identificação criminal, mas a comprovação de autoria/participação em delito. A finalidade é inegavelmente probatória. 


\section{BASE PRINCIPIOLÓGICA: O PRINCÍPIO DO NEMO TENETUR SE DETEGERE E O PRINCÍPIO DA LIBERDADE PROBATÓRIA}

$\mathrm{O}$ princípio do nemo tenetur se detegere, ou o princípio da não autoincriminação, dispõe que ninguém está obrigado a produzir provas contra si mesmo. Este princípio é considerado um direito fundamental do cidadão e, mais especificamente, do acusado. Objetiva proteger o indivíduo contra excessos cometidos pelo Estado, na persecução penal, “incluindo-se nele o resguardo contra violências físicas e morais, empregadas para compelir o indivíduo a cooperar na investigação e apuração dos delitos, bem como contra os métodos proibidos de interrogatório, sugestões e dissimulações" (QUEIJO, 2012, p. 78).

Trata-se de uma modalidade de autodefesa passiva, que é exercida por meio da inatividade do indivíduo sobre quem recai ou pode recair uma imputação. Consiste, assim, na proibição de uso de qualquer medida de coerção ou intimidação ao investigado (ou acusado) em processo de caráter sancionatório para obtenção de uma confissão ou para que colabore em atos que possam ocasionar sua condenação (LIMA, 2016, p. 113).

Conforme Nucci (2014, p. 68):

Trata-se de decorrência natural da conjugação dos princípios constitucionais da presunção de inocência (art. $5^{\circ}$, LVII) e da ampla defesa $\left(\operatorname{art} .5^{\circ}, \mathrm{LV}\right)$ com o direito humano fundamental que permite ao réu manter-se calado (art. $5^{\circ}$, LXIII). Se o indivíduo é inocente, até que seja provada sua culpa, possuindo o direito de produzir amplamente prova em seu favor, bem como se pode permanecer em silêncio sem qualquer tipo de prejuízo à sua situação processual, é mais do que óbvio não estar obrigado, em hipótese alguma, a produzir prova contra si mesmo.

Quem seria, portanto, o titular do direito de não produzir prova contra si mesmo? Em que pese, tudo indique que o destinatário seja apenas a pessoa que se encontra na condição processual de preso, ou que figure como acusado da prática de determinado delito, Lima (2016, p. 114) entende que a doutrina mais aceita é a de que o princípio do nemo tenetur se detegere se preste a proteger não apenas quem está preso, como também aquele que está solto, assim como qualquer pessoa a quem seja imputada a prática de um ilícito criminal. 
$\mathrm{O}$ art. $5^{\circ}$, LXIII, da Constituição Federal dispõe que o preso será informado de seus direitos, entre os quais o de permanecer calado. E, como já dito anteriormente, o nemo tenetur se detegere é uma decorrência natural do direito ao silêncio, previsto no referido artigo. Diante disso, com o objetivo de se evitar uma autoincriminação involuntária por força do desconhecimento da lei, deve haver uma prévia e formal advertência quanto ao direito ao silêncio, sob pena de se macular de ilicitude a prova então obtida (LIMA, 2016, p. 114). O acusado deve, portanto, ser advertido, ademais, que o direito ao silêncio é uma garantia constitucional, de cujo exercício não lhe poderão advir consequências prejudiciais. Dessa forma, torna-se fundamental mencionar as palavras de Lima (2016, p. 115) acerca do assunto:

Nessa esteira, como já se manifestou a $1^{\text {a }}$ Turma do Supremo Tribunal Federal, o direito à informação da faculdade de manter-se silente ganhou dignidade constitucional, porque instrumento insubstituível da eficácia real da vetusta garantia contra a autoincriminação que a persistência planetária dos abusos policiais não deixa perder atualidade. Em princípio, ao invés de constituir desprezível irregularidade, a omissão do dever de informação ao preso dos seus direitos, no momento adequado, gera efetivamente a nulidade e impõe a desconsideração de todas as informações incriminatórias dele anteriormente obtidas, assim como das provas delas derivadas.

Trata-se, o art. $5^{\circ}$, inciso LXIII, de mandamento constitucional semelhante ao famoso aviso de Miranda (Miranda rights ou Miranda warnings) do direito norteamericano, em que o policial, no momento da prisão, tem de ler para o preso os seus direitos, sob pena de não ter validade o que por ele for dito (LIMA, 2016, p. 115).

O princípio da liberdade probatória, por sua vez, consagra o direito das partes de provarem fatos relevantes ao processo, utilizando-se de qualquer meio de prova. Os sujeitos processuais gozam, portanto, de liberdade para a obtenção, apresentação e produção de provas.

Nessa esteira de pensamento, conforme preconiza Lima (2016, p. 873):

Por conta dos interesses envolvidos no processo penal - de um lado, o interesse do indivíduo na manutenção de seu ius libertatis, com o pleno gozo de seus direitos fundamentais, do outro, o interesse estatal no exercício do jus puniendi, objetivando-se a tutela dos bens jurídicos protegidos pelas normas penais - adota-se, no âmbito processual penal, a mais ampla liberdade probatória, seja quanto ao momento ou tema da prova, seja quanto aos meios de prova que podem ser utilizados.

Em concordância com Lima (2016, p. 874), no tocante ao momento da prova, pode-se dizer que, no processo penal, as provas podem ser produzidas a qualquer 
momento. Porém, há exceções a essa regra. Uma dessas exceções diz respeito à apresentação de testemunhas, pois há um momento específico para isso. No entanto, não se pode perder de vista que o art. 156 do CPP permite ao juiz produzir provas de ofício no curso do processo (LIMA, 2016, p. 874).

Quanto aos meios de provas, vigora, no processo penal, ampla liberdade probatória, podendo a parte se valer tanto de meios de prova nominados, quanto de meios de prova inominados (LIMA, 2016, p. 875). Porém, o princípio da liberdade probatória não é absoluto, visto que há limitações para as partes em sua atividade probatória. Diante disso, os meios de prova devem ter sido obtidos de forma lícita e com respeito à ética e à moral, haja vista o preceito constitucional que veda a admissibilidade, no processo, de provas obtidas por meios ilícitos.

Por fim, confrontando brevemente os princípios abordados, do nemo tenetur se detegere e da liberdade probatória, tendo em vista o objeto de interesse do presente artigo, indaga-se: obrigar condenados por crimes violentos ou hediondos a coletar o seu DNA com o objetivo de mantê-los armazenados em banco de dados, é instrumento hábil a qualificar, melhorar, modernizar a persecutio criminis, tornando-a mais eficiente ou, fazer isso, na verdade, é medida desproporcional e irrazoável, que viola a intimidade física do indivíduo e o seu direito constitucional de não ser compelido a produzir prova contra si mesmo?

\section{SOBRE A POLÊMICA DA PROVA PERICIAL OBTIDA POR MEIO DE "BANCO DE DADOS GENÉTICOS"}

Inicia-se esta análise à luz do RE 973.837/MG - que provocou o Supremo Tribunal Federal a discutir sobre a constitucionalidade do art. 9-A da Lei $n^{\circ}$ 7.210/1984 (Lei de Execução Penal), que prevê a obrigatoriedade da extração do DNA e armazenamento em bancos de dados genéticos para fins de identificação do perfil genético do apenado - e da Revisão Criminal 70049748627, que ensejou a realização de um novo julgamento no Tribunal de Justiça do Rio Grande do Sul, por ocasião de uma prova pericial obtida por meio do banco de dados genéticos.

Em relação ao RE 973.837/MG, o Supremo vai decidir se é constitucional a coleta de DNA de condenados por crimes violentos ou hediondos com o objetivo de manter banco de dados estatal com material genético. (NOTÍCIAS STF, 2016, p.1) 
$\mathrm{Na}$ origem, o recurso fora interposto contra acórdão do Tribunal de Justiça de Minas Gerais, em que a defesa de um condenado alega que a medida viola o princípio constitucional da não autoincriminação (nemo tenetur se detegere). Ocorre que, um ano antes do RE 973.837/MG chegar até o Supremo, em 2015, tivemos um caso instigante: pela primeira vez no país, a Justiça brasileira decidiu rever uma condenação sobre um caso de estupro, ocorrido em 2008 no Rio Grande do Sul. Para realizar o novo julgamento, o argumento usado pela defesa foi justamente o surgimento de um fato inédito, obtido através do banco de dados genéticos.

No caso em tela, o acusado havia sido preso depois que a vítima o reconheceu através de uma janela de vidro e o apontou como seu agressor. A única pista do crime ocorrido foi uma mancha de sangue em um colchão, onde a vítima foi violentada durante um assalto. $\mathrm{O}$ material que foi avaliado por peritos revelou que: "a amostra colhida, no entanto, não era compatível nem com o sangue do acusado, coletado pela defesa para entregar à Justiça e confrontar a condenação, nem mesmo com o sangue da vítima”. Ainda durante o reconhecimento, um dos suspeitos do crime havia apontado o acusado (processado) como sendo o único agressor. A vítima confirmou esta versão e o rapaz foi preso. Anos depois, porém, os dados do material genético encontrado no local do crime foram colocados no banco de dados. E, para surpresa da defesa do acusado, as informações genéticas coincidiram com as do mesmo homem que o acusou do estupro na fase de reconhecimento, já condenado por outros crimes da mesma natureza, saliente-se. Tal fato ensejou um segundo julgamento. (G1, 2015).

Não é objetivo do presente trabalho adentrar o mérito do julgado. No entanto, cabe mencionar brevemente que, mesmo com o uso da tecnologia, curiosamente os desembargadores do Tribunal de Justiça do Rio Grande do Sul mantiveram a decisão do primeiro julgamento, proferido em 2008. Naquele ano, o acusado foi condenado por roubo e estupro a 11 anos e meio de prisão. Por maioria, os desembargadores entenderam que o depoimento e reconhecimento pessoal da vítima era suficiente e, portanto, julgaram improcedente a revisão. A maioria manteve o entendimento de que o reconhecimento da vítima era o suficiente para manter a condenação.

Diante disso, pontua-se uma questão em comum: indubitavelmente, os dois casos trazem à tona a discussão acerca da colisão entre direitos fundamentais. De um lado, no RE 973.837/MG, um indivíduo pleitea pelo direito constitucional de não ser 
compelido a produzir prova contra si mesmo, e consequentemente, não ser obrigado a coletar o seu material genético para que este fique armazenado em bancos de dados de perfis genéticos. Por outro lado, na RVCR 70049748627 do TJ/RS, por ocasião do material genético coletado pela defesa, armazenado no banco de dados de perfis genéticos e, posteriormente, cruzado com as informações constantes nele, foi possível identificar um suspeito de participar do crime. Antes disso, nem se cogitava a participação desse indivíduo no evento criminoso.

A uns interessa manter a inviolabilidade do direito constitucional que veda a autoincriminação e, por conseguinte, a vedação da obrigatoriedade da coleta e armazenamento do material genético em bancos de dados de perfis genéticos. A outros interessa a modernização do aparato judicial criminal; modernização das perícias, viabilizando maior amplitude na elucidação de crimes; interessa, com maior ânimo, a liberdade de produzir todas as provas capazes de provar, por exemplo, a sua inocência.

Neste ponto, mister resgatar as lições de Ronald Dworkin e Robert Alexy quanto ao tema da colisão entre direitos fundamentais, suporte teórico basilar para enfrentar a questão. Nas palavras de Dworkin (2002, p.39-42), é de natureza lógica a diferença entre os princípios jurídicos e as regras jurídicas:

[...] as regras são aplicáveis à maneira tudo-ou-nada. Dados os fatos que uma regra estipula, então ou a regra é válida, e neste caso a resposta que ela fornece deve ser aceita, ou não é válida, e nesse caso em nada contribui para a decisão. Noutro giro, quando os princípios se intercruzam, aquele que vai resolver o conflito tem de levar em conta a força relativa de cada um - a dimensão do peso ou importância, dimensão que as regras não têm.

Para Alexy (2008, p. 90-91):

[...] o ponto decisivo na distinção entre regras e princípios é que princípios são normas que ordenam que algo seja realizado na maior medida possível dentro das possibilidades jurídicas e fáticas existentes. Princípios são, por conseguinte, mandamentos de otimização. Quanto as regras, por outro lado, são normas que são sempre ou satisfeitas ou não satisfeitas. Se uma regra vale, então, deve se fazer exatamente aquilo que ela exige; nem mais, nem menos.

Portanto, havendo conflito entre princípios, deve-se buscar a conciliação entre eles, aplicando-se cada um deles em extensões variadas, conforme a relevância que apresentarem no caso concreto, não sendo admitida a exclusão de um deles do ordenamento jurídico. A busca por soluções conciliadoras diante das colisões de direitos 
fundamentais exige o manuseio do postulado da proporcionalidade e da técnica de ponderação (MASSON, 2016, p. 210).

O juízo de ponderação conecta-se ao postulado da proporcionalidade, exigindo que o sacrifício de um direito seja útil para a solução do problema, isto é, que não exista outro meio menos danoso para atingir o resultado desejado e que seja proporcional em sentido estrito. Assim, devem ser comprimidos no menor grau possível os direitos em colisão, de maneira a preservar a sua essência, o seu núcleo fundamental (MENDES, 2015, p. 183).

Indubitavelmente, tendo em vista a questão a ser enfrentada pelo Supremo no RE 973.837/MG, uma solução possível para esta colisão entre princípios, seja ela qual for, perpassa por uma leitura constitucional à luz de tais suportes teóricos basilares ${ }^{4}$.

Por ocasião do julgamento do RE 973.837/MG, nos dias 25 e 26 de maio de 2017, o Supremo Tribunal Federal realizou audiência pública para ouvir a opinião de especialistas em genética e sua aplicação à investigação forense, além de estudiosos, juristas e autoridades internacionais no tema. A audiência pública foi convocada pelo ministro Gilmar Mendes, relator do Recurso Extraordinário, com repercussão geral reconhecida pelo Supremo.

Em resumo, esses foram os principais argumentos apresentados pelos especialistas na audiência pública: "a coleta de DNA de condenados por crimes hediondos ou de natureza grave contra a pessoa não fere o direito à privacidade nem o princípio da não autoincriminação (nemo tenetur se detegere), além de representar um avanço nas técnicas de investigação forense”. (CONJUR, 2017).

Ingo Bastisch, perito do Departamento Federal de Polícia Criminal da Alemanha, disse que a análise de DNA já foi considerada constitucional pelo Judiciário

\footnotetext{
${ }^{4}$ A exemplo do Brasil, os limites dos poderes do estado de colher material biológico de suspeitos ou condenados por crimes, de traçar o respectivo perfil genético, de armazenar os perfis em bancos de dados e de fazer uso dessas informações são objeto de discussão em diversos sistemas jurídicos. A Justiça dos EUA, por exemplo, já enfrentou a questão e considerou constitucional o banco de dados. Por lá, o entendimento é de que o DNA é uma evidência física e que não se trata de autoincriminação. Nos anos 80, o exame de DNA se tornou muito popular nos EUA e vários estados aprovaram leis para permitir a coleta de amostras do material genético de suspeitos de crimes. O FBI, então, reconheceu a importância do assunto e iniciou um projeto para que houvesse a troca dessas informações pelos estados. Em 1994 foi editada uma lei federal que permitiu estabelecer um banco nacional de dados. Ao longo do tempo, foram sendo criadas medidas para garantir a privacidade das pessoas, como por exemplo, a obrigatoriedade de que apenas os investigadores possam compartilhar as informações. (CONJUR, 2017)
} 
alemão. Lembrou que o uso do registro do DNA é bastante usado nos países europeus e bem aceito no processo criminal. Afirmou também que o uso mais extensivo do DNA pode prevenir crimes. Afirmou ainda que, por lá, as amostras não podem conter o nome da pessoa que teve o material coletado, mas apenas as iniciais. "O banco está conectado ao histórico policial da pessoa. Se a ficha é encerrada, o banco de dados é apagado também”. (CONJUR, 2017).

A identificação criminal é feita rotineiramente, e a coleta de DNA é apenas mais uma forma de identificação, sem nenhum tipo de invasão de privacidade, argumentou o perito criminal Guilherme Jacques. Além disso, o uso indevido do banco é considerado crime, de acordo com a lei no 12.654/2012. Como exemplo de eficiência no cruzamento genético promovido pelo banco em investigações, Guilherme Jacques citou um caso que ocorreu em março deste ano, quando a Polícia Militar de Minas Gerais prendeu o cantor gospel Renato Bandeira, de 30 anos, em Belo Horizonte. Ele era acusado de ter estuprado uma mulher na capital mineira. Após ser detido, teve o DNA coletado e, com o cruzamento, concluiu-se que ele também seria o responsável por cinco crimes da mesma natureza cometidos no DF, em 2014, na região entre Taguatinga e Águas Claras. Segundo Jacques, o caso não teria sido solucionado se não fosse a lei de 2012. Ele também salientou que o banco diminui os riscos de se condenar um inocente, muitas vezes apontado como culpado baseado apenas em retrato falado, o que é muito menos eficiente do que a comparação genética. (CONJUR, 2017).

\section{CONSIDERAÇÕES FINAIS}

Chega-se ao final desse ensaio retomando a questão inicial da (in)constitucionalidade sobre a obrigatoriedade da coleta de DNA de condenados por crimes violentos ou hediondos, com o objetivo de mantê-los armazenados em um banco de dados genéticos à disposição do Estado. A discussão que foi levada à audiência pública requer, no mínimo, um cuidado minucioso dos juristas, bem como um entendimento da população sobre o que se buscou discutir em público: de um lado está a elucidação de crimes graves e violentos e um melhor desenvolvimento da justiça penal com a extração obrigatória de material genético; de outro, um direito fundamental de intimidade e não produção de provas contra si mesmo. 
Nesse contexto de modernização da persecutio criminis, com a criação do Banco Nacional de Perfis Genéticos e a Rede Integrada de Bancos de Perfis Genéticos, tem-se uma tensão dentre princípios fundamentais que precisa ser observada cuidadosamente pelos Tribunais Superiores e pela sociedade.

Enfatiza-se, portanto, que este ensaio nunca se propôs a indicar qualquer saída para a celeuma em questão, ou mesmo apontar diagnósticos e caminhos a serem seguidos, mas tão somente apresentar um problema sério e necessário que precisa ser publicizado e dialogado exaustivamente no âmbito acadêmico, para que assim, possa-se vislumbrar minimizações de afrontas ao Estado de Democrático de Direito e, consequentemente, ao devido processo penal constitucional. Luta-se, assim, por um processo penal mais justo e adequado, tendo sempre como direção norteadora os preceitos constitucionais garantidores de direitos fundamentais.

\section{REFERÊNCIAS}

ALEXY, Robert. Teoria dos Direitos Fundamentais. Trad. Virgílio A. Da Silva. São Paulo: Malheiros, 2008.

CONJUR. Coleta de DNA de criminosos é avanço na investigação forense, dizem especialistas. Disponível em: < http://www.conjur.com.br/2017-mai-25/especialistascoleta-dna-avanco-investigacao-forense >. Acesso em: 13 jul. 2017.

DWORKIN, Ronald. Levando os direitos a sério. Tradução e notas: Nelson Boeira. São Paulo: Martins Fontes, 2002.

G1, Rio Grande do Sul. Pela $1^{\text {a }}$ vez, Justiça refaz julgamento de preso com base em banco de DNA, 2015. Disponível em: < http://g1.globo.com/rs/rio-grande-dosul/noticia/2015/09/pela-1-vez-justica-refaz-julgamento-de-preso-com-base-em-bancode-dna.html >. Acesso em: 22 de maio, 2017.

JACQUES, Guilherme Silveira; MINERVINO, Aline Costa. Aspectos éticos e legais dos bancos de dados de perfis genéticos. Perícia Federal, Brasília, ano 9, nº 26, p. 17 -

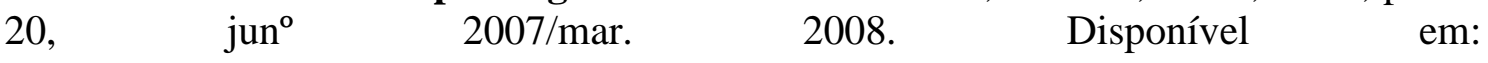
<http://www.apcf.org.br/Portals/0/revistaAPCF/26.pdf> Acesso em: 13 jul. 2017.

LIMA, Renato Brasileiro de. Código de Processo Penal Comentado. Salvador: Juspodivm, 2016.

LIMA, Renato Brasileiro de. Manual de processo penal: volume único - 4. ed. rev., ampl. e atual. Salvador: Editora JusPodivm, 2016.

LOPES JR., Aury. Direito Processual Penal. 14. Ed. - São Paulo: Saraiva, 2017.

LOPES, Jr., Aury. Lei 12654/2012: é o fim do direito de não produzir provas contra si mesmo (Nemo tenetur se detegere)? Boletim IBCCRIM, ano 20, $\mathrm{n}^{\circ}$ 236, Julho/2012. 
MASSON, Nathalia. Manual de direito constitucional - 4. Ed. rev. ampl. atual. Salvador: JusPODIVM, 2016.

MENDES, Gilmar Ferreira; BRANCO, Paulo Gustavo Gonet. Curso de Direito Constitucional. $10^{\mathrm{a}}$ ed. São Paulo: Saraiva, 2015.

NUCCI, Guilherme de Souza. Manual de processo e execução penal. 11. Ed. Rev., atual e ampl. Rio de Janeiro: Ed. Forense, 2014.

QUEIJO, Maria Elizabeth. O direito de não produzir provas contra si mesmo: o princípio nemo tenetur se detegere e suas decorrências ao processo penal - 2. ed. São Paulo: Saraiva, 2012.

STF, notícias. STF vai analisar constitucionalidade de banco de dados com material genético de condenados, 2016. Disponível em: < http://www.stf.jus.br/portal/cms/verNoticiaDetalhe.asp?idConteudo=319797 >. Acesso em: 22 de maio, 2017.

TÁVORA, Nestor; ALENCAR, Rosmar Rodrigues. Curso de direito processual penal. 8. Ed. Salvador: Ed. Juspodivm, 2013. 